\title{
Erişkin atipik kızamık olgusu
}

\author{
Adult atypical measles case
}

\section{Esra YÜKSEKKAYA@ Salih CESUR@, Çiğdem Ataman HATIPOĞLU@ Esra Kaya KILIÇ@, Sami KINIKLI}

Ankara Eğitim ve Araştırma Hastanesi, Enfeksiyon Hastalıkları ve Klinik Mikrobiyoloji Kliniği, Ankara/TÜRKiYE

\section{Öz}

Atipik kızamık ilk kez 1965 yılında Rauh ve Schmidth tarafından tanımlanmıştır. Atipik kızamık, daha önce ölü kızamık aşıSı ile aşılanmış bireylerin kızamık virüsüyle karşılaşmasıyla ortaya çıkan, tipik kızamıktan farklı klinik tablo olarak tanımlanır. Bu durum nadiren canlı aşıya bağlı olarak da bazı bireylerde görülebilir. Bu yazıda, daha önce kızamık aşısı anamnezi bilinmeyen, 37 yaşında bir kadın hastada yüksek ateş, ekstremitelerden başlayıp gövdeye ve yüze yayılan makülopapüler döküntülerle karakterize bir atipik kızamık olgusu sunduk.

Anahtar kelimeler: erişkin; atipik kızamık; klinik seyir

\section{ABSTRACT}

Atypical measles was first recognized by Rauth and Schmidt. Atypical measles has been described in persons who were exposed to wildmeasles virus several years after they were vaccinated with killed measles vaccine and it is defined as different clinical picture from typical measles. This condition also occurs, but rarely, in some individuals vaccinated with attenuated virüs vaccine. In this report, we presented 37 years of female patient with a unknown history of measles vaccination, who presented with high fever, maculopapular rash starting on the extremities and spreading to the body and face.

Keywords: adult; atypical measles; clinical course

Sorumlu Yazar*: Salih Cesur, Ankara Eğitim ve Araştırma Hastanesi, Enfeksiyon Hastalıkları ve Klinik Mikrobiyoloji Kliniği, Ankara/TÜRKiYE E-posta: scesur89@yahoo.com

ORCID: 000-0003-4960-7375

Recevied 25.09.2017 accepted 31.10.2017

Doi: 10.18663/tjcl.339919 


\section{Giriş}

Atipik kızamık, daha önce ölü kızamık aşısı ile aşılanmış bireylerin vahşi tip kızamık virüsüyle karşılaşmasıyla veya nadiren de canlı aşıya bağlı olarak ortaya çıkan, tipik kızamıktan farklı klinik tablo olarak tanımlanır [1,2]. Atipik kızamıkta ateş ve bir iki gün süren ağrılı prodromdan sonra döküntü ortaya çıkar. Klasik kızamığın aksine döküntüler periferden başlar, döküntüler ürtikeriyal, makülopapüler, hemorajik,veziküler veya bunların kombinasyonu şeklinde olabilir [2].

Bu yazıda, daha önce kızamık aşısı öyküsü bilinmeyen,37 yaşında bir kadın hastada yüksek ateş, ekstremitelerden başlayıp gövdeye yayılan makülopapüler döküntülerle karakterize bir atipik kızamık olgusu sunuldu.

\section{Olgu}

Otuzyedi yaşında kadın hasta 3 gün önce başlayan $39^{\circ} \mathrm{C}^{\prime} y e$ kadar yükselen ateş, boğaz ağrısı ve vücutta döküntü yakınmaları ile acil servise başvurdu. Anamnezinden döküntülerin kollarından ve bacaklarından başlayıp tüm vücuda yayıldığı, acil servise başvurusundan önce ateşi için birkaç gün süreyle parasetamol ve ibuprofen kullandığı öğrenildi. Öz geçmişinde yurt dışı seyahat, hayvan besleme ve evde benzer şikayeti olan aile bireyi yoktu. Soygeçmişinde özellik saptanmadı.

Hasta ateş ve döküntü nedeni araştırılmak üzere enfeksiyon hastalıkları kliniğine yatırıldı. Fizik muayenesinde; ateş: 37.5 ${ }^{0} \mathrm{C}$, kan basıncı: 100/60 mmHg, bilinci açık, orofarenks hiperemikti. Ekstremiteler, gövde ve yüzde makülopapüler tarzda nadiren veziküler döküntüler mevcuttu (Resim 1-2). Hastadan resimlerin yayınlanması için yazılı izin alındı.

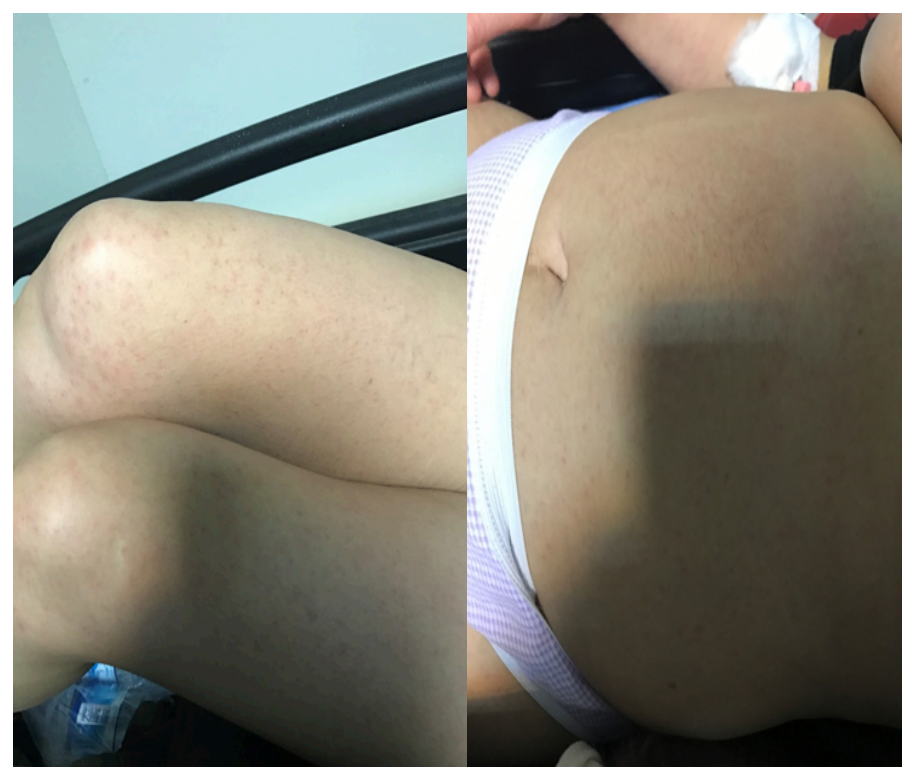

Resim 1. Ekstremiteler ve gövdedeki makülopapüler döküntü

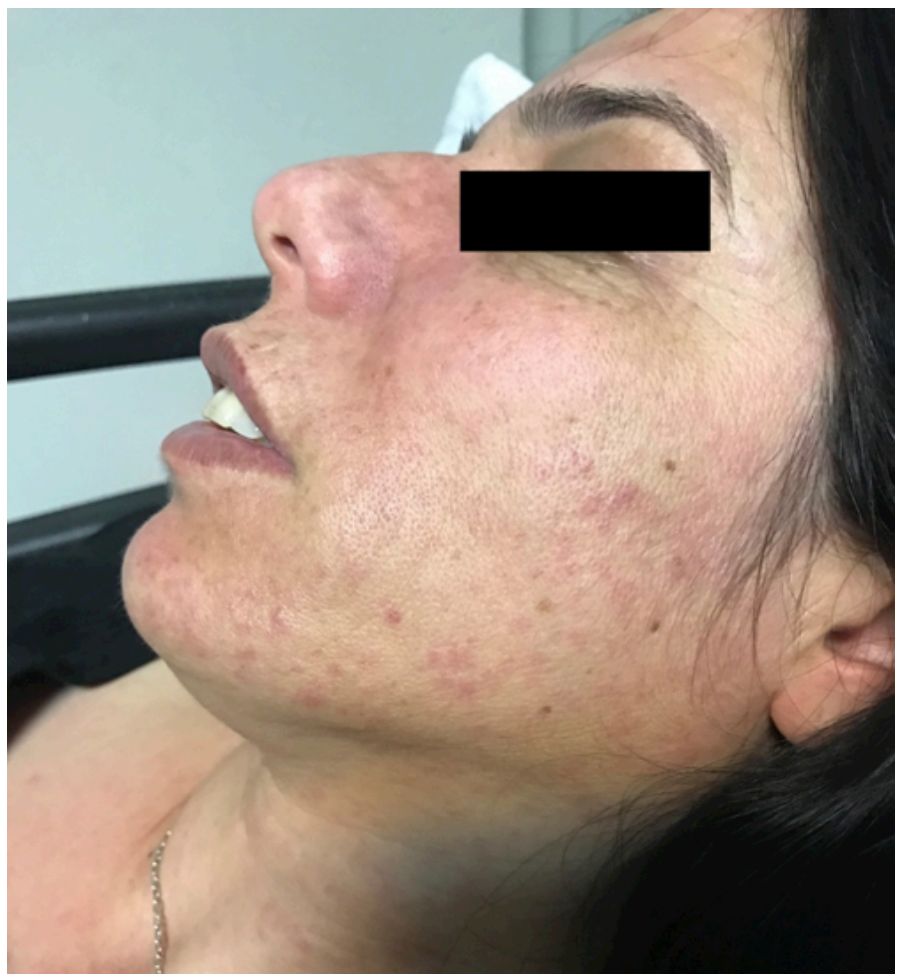

Resim 2. Hastanın yüz bölgesindeki makülopapüler döküntüsü

Orofarenkste Koplik lekesi görülmedi. Diğer sistem muayeneleri normaldi.Laboratuvar testlerinde; lökosit sayısı: 6.600/mm3, CRP: 30 mg/L (normali:0-5 mg/L), sedimentasyon hızl: $22 \mathrm{~mm} / \mathrm{saat}$,

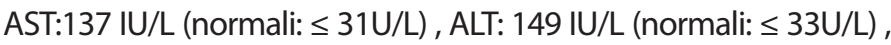
GGT: 206 U/L (normali: <=42), diğer tetkikleri normaldi. Abdominal ultrasonografisinde patoloji saptanmadı. Postero-anterior akciğer grafisi normaldi. Anti-HVA-IgM: negatif, Anti-HCV: negatif, HBsAg: negatif, HBclgM:negatif, Anti-HIV: negatif, AntiCMV-lgM: negatif, EBNA-VCA IgM:negatifti. Yatışının ilk günü konjuktivada hiperemi saptanan hastaya göz hastalıkları kliniği tarafından topikal göz damlası önerildi. Ateşli dönemde hastadan kan, boğaz ve idrar kültürleri alındı. Kültürlerinde üreme olmadı. Dermatoloji kliniğine konsülte edilen hastada atipik kızamık, ilaç erüpsiyonu ön tanıları düşünüldü. Yatışının ilk iki günü ara ara 37.5 C-38C arası ateşi olan hastaya semptomatik tedavi uygulandı, yatışının üçüncü gününde döküntüleri geriledi ve ateşi olmadı. Hastadan istenen RubeolaIgM ELISA testi sonucu pozitif olarak saptandı.Yatışının beşinci gününde hasta kontrole gelmek üzere taburcu edildi. İki hafta sonraki kontrol tetkiklerinde AST, ALT ve GGT değerlerinin normal sınırlarda olduğu saptandı.Sunduğumuz olguda hepatit virüslerinin negatif olması ve toksik ilaç maruziyeti olmaması nedeniyle hepatitin atipik kızamığa bağlı olabileceğini düşündük. Çalışma için yerel etik kurul onayı alındı. Hasta onam formları imzalatıldı.

\section{Tartışma}

Kızamık (Rubeola, measles), sıklıkla çocukluk çağında görülen, 
ateş ve döküntüyle seyreden, aşıyla önlenebilen bir infeksiyon hastalığıdır. Hastalığın etkeni Paramyxoviridae ailesinin Morbili virüs cinsinde yer alan, tek iplikli, seğmenter yapı göstermeyen Rubeola virüstür. Tipik kızamık tablosu yüksek ateş, öküsürük, burun akıntısı ve konjuktivit semptomları ile başlar. Prodromal dönemden sonra başlayıp perifere yayılan (sentrifugal) makülopapüler tarzda döküntüler görülür. Döküntüler birleşme eğilimindedir. Ağız mukozasında sıklıkla molar diş hizasında görülen, bazen yanak mukozasının diğer kısmlarına da yayılabilen,küçük parlak kırmızı renkte lekenin içerisinde beyaz renk beneklerle karakterize enatem Koplik lekesi olarak isimlendirilir ve hastalık için patognomiktir. Koplik lekesi döküntülerin başlamasından önceki iki gün içerisinde ortaya çıkar, 12-18 saat sonra hızla kaybolur [1-3]. Atipik kızamık, tipik kızamıktan klinik olarak farklılık gösteren bir tablo olup,ilk kez 1965 yılında tanımlanmıştır [1,3]. Atipik kızamık olgularında ateşle birlikte atipik döküntü, döküntülerin vücuda yayılım şeklinde farklılık, ekstremitelerde ödem, akciğerlerde intertisiyel infiltratlar ,hepatit ve bazen plevral efüzyon görülebilir $[1,2,4]$. Atipik kızamıkta döküntüler tipik kızamığın aksine periferden başlar (sentripedal) merkeze doğru yayılır. Sunduğumuz olguda da döküntüler ekstremitelerden başlayıp gövdeye yayılmıştı. Döküntüler ürtikeriyal, makülopapüler, hemorajik,veziküler veya bunların kombinasyonu şeklinde olabilir [2]. Olgumuzda döküntüler ağırlıklı olarak makülopapüler tarzda olmakla birlikte nadirde olsa veziküler tarzda döküntüler de mevcuttu. Demirdağ ve ark.[1 ] 36 yaşında bir kadın hastada avuç içinden başlayıp tüm vücuda yayılan makülopapüler döküntü, kuru öksürük ve dispine yakınmaları olan bir atipik kızamık olgusu bildirimişlerdir.Olguda akciğer grafiside intertisiyel tutulum, toraks bilgisayarlı tomografisinde ise akciğerlerde nodüler opasiteler saptanmıştır. Olguda solunum sıkıntısının atipik kızamık seyrinde görülebilen akciğer tutulumuna bağlı olabileceği bildirilmiştir. Kızamıkla birlikte hepatit görülebilir ve sıklıkla asemptomatiktir. Kızamık seyrinde görülen hepatit iki formda görülebilir. İlk form erken ortaya çıkar ve birkaç gün içinde düzelir. İkinci form kolestaz ve sarılıkla birliktedir Bu form kızamık gerilemeye başladığında hepatit belirgin hale gelir ve hepatit iki hafta ve daha fazla sürebilir [5]. Pasha ve ark.[6] 284 kızamık olgusunu retrospektif olarak değerlendirdikleri çalışmasında 138 olguda (\%48.6) karaciğer disfonksiyonu bildirmişlerdir. Aynı çalışmada ateş ve döküntü tüm olgularda saptanırken, Koplik lekesi \%38'inde, akciğerlerde patolojik dinleme bulgusu ise \%76'sında saptanmıştır. Khatib ve ark.[5] kızamığa bağlı hepatit gelişen 27 olguyu değerlendirdikleri çalışmada olguların 7'sinin atipik kızamık olgusu olduğunu bildirmişlerdir.Olguların sadece 3'ünde kızamık kolestaz ve sarılıkla seyrederken, diğerlerinde ise asemptomatik hepatit şeklinde seyretmiş̧tir. Erişkin hastalarında kızamık seyrinde görülen hepatitin prognozu iyidir.Karaciğer biyopsisinde kızamık virüsü RNA'sı polimeraz zincir reaksiyonu ile gösterilerek tanı doğrulanabilir [7,8].Giladi ve ark.[9] kızamık olgularında hepatit sıklığını \%71-89 arasında, Tartar ve ark. [8] ise \%63 oranında bildirmişlerdir. Sunduğumuz olguda karaciğer transaminaz değerlerindeki yüksekliğin hepatit markerlarının negatif olması, toksik ilaç kullanımı öyküsü olmaması, hepatobiliyer USG'sinin normal olması ve transaminaz değerlerinin normal değerlere dönmesi nedeniyle atipik kızamığa bağlı hepatit olabileceğini düşündük. Olgumuzda hepatitle birlikte kolestaz ve sarılık görülmemiştir. Koplik lekeleri döküntüden önceki iki gün içerisinde ortaya çıkıp hızla kaybolduğundan olgumuzda Koplik lekelerinin saptanmama nedeni döküntüler başladıktan sonra hastanın kliniğimize başvurması nedeniyle olabilir. Tartar ve ark.[8] 19 erişkin kızamık hastasını değerlendirdikleri çalışmalarında en sık görülen belirtileri yüksek ateş (18 olguda), döküntü (19 olguda) ve öksürük (15 olguda), en sık görülen fizik muayene bulgusunu ise makülopapüler döküntü (19 olguda) ve Koplik lekesi (11 olguda) ve olarak belirlemişlerdir. Olguların laboratuvar bulgularında; 11 'inde (\%57.8) AST yüksekliği,10'unda (\%52.6) ALT yüksekliği ,13'ünde (\%68.4) lökopeni bildirmişlerdir. Sunduğumuz olguda lökopeni saptanmazken, ALT ve AST değerlerinde normalin yaklaşık 4 katı yükseklik saptandı.

Turhan ve ark.[3] 21 yaşında bir erkek hastada periferden başlayıp merkeze doğru yayılan, el ayası ve ayak tabanında da görülen, ürtikeriyal, hemorajik ve veziküler tarzda döküntü, pnömoni ve hepatit ile karakterize atipik kızamık bildirmişlerdir. Olgumuzda da döküntünün yayılma şekli, hepatit görülmesi ve Koplik lekesinin görülmemesi nedeniyle Turhan ve ark. olgusuyla benzerlik göstermektedir.

Atipik kızamık olguları suçiçeği, kayalık dağlar benekli ateşi, Henoch-Schönlein purpurası , ilaç erüpsiyonu, veya toksik şok sendromu ile karışabilir [1,2].Sunduğumuz olguda ayırıcı tanı olarak ilaç erüpsiyonu düşünülmüş, ancak; Rubeola IgM ELISA testinin pozitif saptanması ile atipik kızamık tanısı kesinleştirilmiştir.

Atipik kızamık tipik kızamıktan daha uzun seyir göstermesi nedeniyle daha ciddi seyir gösterme eğilimindedir. Olgumuzda ciddi seyir görülmedi, hasta semptomatik tedavi ile tamamen düzeldi. Atipik kızamıklı hastalar başlangıçta saptanamaz veya çok düşük düzeyde antikor seviyesine sahiptir. Bundan sonra 
kızamıgın beklenmedik bulgularından sonra oldukça yüksek titrede antikor titresi ortaya çıkar. Atipik kızamık hastalarından virüs izole edilmez ve diğer hastalara bulaş olmaz. Bu sendromun patogenezinin kızamığa karşı kismi yanıt veren konakta hipersensitiviteye bağlı olduğu düşünülmektedir. Atipik kızamığın rekürrensi de bildirilmemiştir [2].

Atipik kızamık olguları kızamık aşısının uygunsuz transportu, uygunsuz şartlarda depolanmaması, soğuk zincir koşullarına uygun muhafaza edilmemesi durumunda sağlıklı bireylere uygulanması sonucunda da ortaya çıkabilir [3].

\section{Sonuç}

Sunduğumuz olguda da olduğu gibi kızamık aşısı öyküsü bilinmeyen, yüksek ateş, atipik seyirli makülopapüler döküntü ile başvuraran erişkin hastalar atipik kızamık açısından araştııılmalıdır.

\section{Kaynaklar}

1. Demirdal T, Sarı ÜS, Kaptan F, Türker N, Örmen B, Sezak N. Nadir görülen bir olgu: atipik kızamık. Med Bull Haseki 2016; 54: 50-52.

2. Gershon AA. Measles virüs (Rubeola). In: Bennett JE, Dolin R, Blaser MJ, eds. Mandell, Douglas, and Bennett's Principles and Practice of Infectious Diseases. 8th ed. Philadelphia, PA: Elsevier Saunders; 2015; 106: 1318-27.
3. Turhan V, Adam E, Gül HE, Beşirbelioğlu AB, Pahsa A. Atipik kızamık sendromu (Bir olgu nedeniyle) Flora 2007; 12: 157-60.

4. Frey HM, Krugman S. Atypical measles syndrome: unusual hepatic, pulmonary, and immunologic aspects. Am J Med Sci. 1981; 281: 51-55.

5. Khatib R, Siddique M, Abbass M. Measles associated hepatobiliary disease: an overview.Infection 1993; 21: 112-14.

6. Pahsa A, Özsoy MF, Altunay H,ve ark. Erişkinlerde Kızamık: 284 Olgunun Retrospektif Değerlendirilmesi. Flora 1999; 4: 200-205.

7. Satoh A, Kobayashi $H$, Yoshida $T$ at al. Clinicopathological study on liver dysfunction in measles, Intern Med 1999; 38: 454-57.

8. Tartar AS, Balin ŞÖ, Kırık Y, Akbulut A, Demirdağ K. Erişkin yaş grubunda kızamık vakalarının irdelenmesi. ANKEM Derg 2016; 30: 91-96.

9. Giladi M, Schulman A, Kedem R, Danon YL. Measles in adults: a prospective study of 291 consecutive cases, $\mathrm{Br}$ Med J (Clin Res Ed) 1987; 295: 1314. 